Jackson, G. A. (1957). Lancet, 1, 637. James, D. G., and Thomson, A. D. (1955). Quart. F. Med., 24,

Kenney, M., and Stone, D. J. (1963). Amer. Rev. resp. Dis., 87, 504.

Lawrence, H. S. (1952). f. Immunol., 68, 159.

Medical Research Council (1956). Brit. med. f., 1, 413.

- (1959). Ibid., 2, 379.

Nelson, C. T., and Schwimmer, B. (1957). 7. invest. Derm., 28, 55.

Pyke, D. A., and Scadding, J. G. (1952). Brit. med. f., 2, 1126.

Scadding, J. G. (1960). Ibid., 2, 1617.
Siltzbach, L. E. (1961a). Amer. Rev, resp. Dis., 84, Suppl., p. 89.

(1961b). F. Amer. med. Ass., 178, 476

(1961c). Amer. F. Med., 30, 495.

and Ehrlich, J. C. (1954). Ibid., 16, 790.

Sones, M., and Israel, H. L. (1954). Ann. intern. Med., 40, 260.

Sparrow, H., and Carré, G. (1960). Rev. Tuberc. (Paris), 24, 389.

Steigleder, G. K., Silva, A. jun, and Nelson, C. T. (1961). Arch. Derm. 84, 828 .

Stewart, C. B., and Beckwith, C. J. W. (1960). Canad. med. Ass. F., 83, 1.

Ustvedt, H. J. (1951). f. Oslo Cy Hosp., 1, 64.

\title{
Studies on the Secretion of Human-pituitary-growth Hormone
}

\author{
W. M. HUNTER,* B.SC. ; F. C. GREENWOOD,* M.SC., PH.D.
}

Brit. med. F., 1964, 1, 804-807

The development of a sensitive and specific radio-immunoassay for human growth hormone in plasma (Hunter and Greenwood, $1962,1964)$ has allowed studies of the levels of human growth hormone in the varying physiological states represented by childhood, adolescence (Greenwood, Hunter, and Marrian, 1964), and pregnancy and lactation (Greenwood, Hunter, and Klopper, 1964).

Acute changes in growth-hormone secretion have been induced in normal adult subjects by Roth, Glick, Yalow, and Berson (1963a, 1963b). These authors have shown that the secretion of growth hormone as measured by plasma-growthhormone levels is suppressed by the administration of glucose. Secretion was stimulated by hypoglycaemia, inhibition of glucose utilization, prolonged fasting, and muscular exercise. Results presented here confirm their findings and also suggest that growth-hormone secretion is reduced but not suppressed by protein administration. Results obtained from a series of 11 subjects during hypoglycaemia induced by insulin or tolbutamide suggest that the response in growth-hormone secretion to this stimulus could be of value in the investigation of patients with suspected pituitary disorders.

\section{Material and Methods}

With the exception of the hospital patients noted in Table II and the Chart, subjects were healthy adult volunteers with no history of endocrine disease, aged from 24 to 48 .

The diagnoses, insulin or tolbutamide doses, and blood-sugar values recorded for the hospital patients shown in Table II and the Chart were kindly supplied by clinical colleagues at the hospitals mentioned in the acknowledgments. Different methods for the analysis of blood sugar were used for these patients and for the normal subjects. Values recorded are comparable only for each patient.

Human growth hormone was estimated by a radio-immunoelectrophoretic technique (Hunter and Greenwood, 1962). The estimations were carried out with heparinized plasma $(0.05-$ $0.4 \mathrm{ml}$. of a $1 / 4$ dilution) in assays using $0.2 \mu \mathrm{mg} .{ }^{131} \mathrm{I}$-labelled growth hormone. The standards in the assay were from a laboratory reference preparation of growth hormone (I.C.R.F. Batch 3) prepared by the method of Raben (1959). This has an immunological potency of $124 \%$ of the Medical Research Council human growth hormone R.5. The levels of the first standard were 0.1 or $0.2 \mu \mathrm{mg}$. ; sensitivities of growth hormone

\footnotetext{
* Scientific Staff, Imperial Cancer Research Fund, Lincoln's Inn Fields, London.
}

in plasma were $>1$ or $>2 \mu \mathrm{mg} . / \mathrm{ml}$. plasma respectively. The precision of the measurements in plasma over the ranges 1-5, $5-10$, and $10-40 \mu \mathrm{mg} . / \mathrm{ml}$. were $\pm 0.51, \pm 0.95$, and \pm 2.22 $\mu \mathrm{mg}$. respectively. These values are estimates of the standard deviations of results from their means (Hunter and Greenwood, 1964).

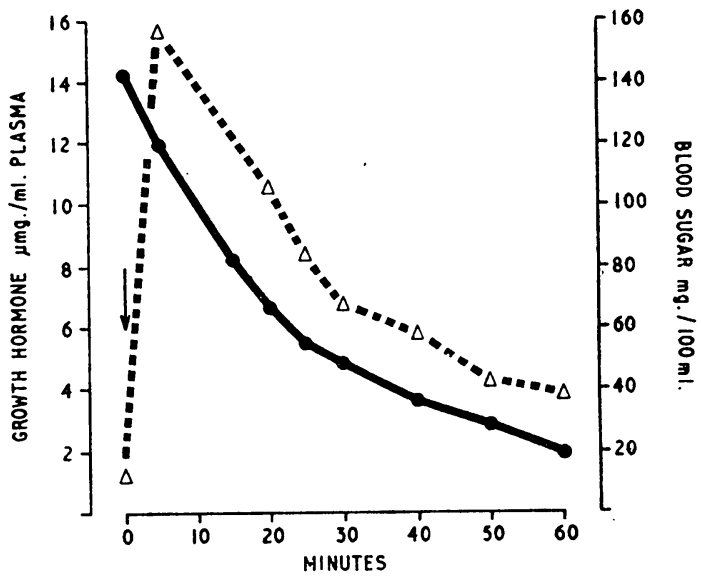

Effect of intravenous glucose on plasma-growthhormone levels. Plasma-growth-hormone (- - ) and blood-sugar $(--\triangle--\triangle--)$ levels were measured before and after intravenous glucose $(25 \mathrm{~g}$.) in a patient with a suspected islet-cell tumour. A blood sample was taken and glucose in ected at the point indicated by the arrow. This study was carried out by Dr. V. Marks.

\section{Results}

\section{Overnight Fasting Levels of Growth Hormone}

Table I shows the levels of growth hormone found in healthy adults after an overnight fast (14 hours). The previous dietary habits were not recorded. Samples of plasma from 18 adults two to three hours after a meal have previously been reported (Greenwood, Hunter, and Marrian, 1964) and a mean value of $0.55 \mu \mathrm{mg}$. \pm 0.68 (standard deviation) was obtained. In nine of these subjects the level of growth hormone was indistinguishable from zero, in common with patients after hypophysectomy for metastatic breast cancer. In contrast detectable growth hormone was present in the normal subjects shown in Table I, and the mean level with subject $G$ excluded was $2.92 \mu \mathrm{mg}$. \pm 2.95 (standard deviation). One subject (E, Table I) was tested on three occasions at mid-morning and no growth hor- 
mone was detected. The results show that an overnight fast in all subjects stimulates growth-hormone secretion but the degree of stimulation varies from subject to subject. In the three subjects (B, F, and G, Table I) studied on two occasions, the fasting level of blood sugar and of growth hormone bore an inverse relationship. The absolute levels of an individual's blood sugar and growth hormone or their weight are not simply related, however. The results on the normal woman (G) were surprising, since the values are within the range of values found for acromegalic subjects $72.3 \pm 69.3 \mu \mathrm{mg} . / \mathrm{ml}$. (Hunter and Greenwood, 1964). A similar single high value of $>50 \mu \mathrm{mg}$. growth $/ \mathrm{ml}$. plasma in a normal subject was also reported by Roth et al. (1963b).

\begin{tabular}{|c|c|c|c|c|c|c|}
\hline \multirow{2}{*}{ Subject } & \multicolumn{2}{|c|}{ Weight } & \multicolumn{2}{|c|}{ Height } & \multirow{2}{*}{$\begin{array}{c}\text { Growth } \\
\text { Hormone } \\
\text { ( } \mu \text { mg./ } \\
\text { ml. })\end{array}$} & \multirow{2}{*}{$\begin{array}{c}\text { Blood } \\
\text { Sugar } \\
\text { (mg./ } \\
100 \mathrm{ml} .\end{array}$} \\
\hline & lb. & kg. & in. & $\mathrm{cm}$. & & \\
\hline \multicolumn{7}{|c|}{ Men } \\
\hline A & 133 & $60 \cdot 3$ & 69 & 175 & 0.5 & 65 \\
\hline B & 140 & 63.5 & 69 & 175 & $\begin{array}{l}7 \cdot 2 \\
0.7\end{array}$ & $\begin{array}{l}64 \\
78\end{array}$ \\
\hline $\begin{array}{l}\mathrm{C} \\
\mathrm{D} \\
\mathrm{E} \\
\mathrm{F}\end{array}$ & $\begin{array}{l}147 \\
166 \\
170 \\
189\end{array}$ & $\begin{array}{l}66 \cdot 7 \\
75 \cdot 3 \\
77 \cdot 1 \\
85 \cdot 7\end{array}$ & $\begin{array}{l}69 \\
70 \\
70 \\
70\end{array}$ & $\begin{array}{l}178 \\
178 \\
178 \\
178\end{array}$ & $\begin{array}{l}0.6 \\
1.7 \\
1.2 \\
1.6 \\
8 \cdot 1\end{array}$ & $\begin{array}{r}80 \\
66 \\
70 \\
102 \\
82\end{array}$ \\
\hline \multicolumn{7}{|c|}{ Women } \\
\hline G & 110 & $49 \cdot 9$ & 70 & 178 & $\left\{\begin{array}{r}46 \cdot 0 \\
116 \cdot 0\end{array}\right.$ & $\begin{array}{l}78 \\
68\end{array}$ \\
\hline $\begin{array}{l}\mathbf{H} \\
\mathbf{J} \\
\mathbf{K}\end{array}$ & $\begin{array}{l}194 \\
211 \\
218\end{array}$ & $\begin{array}{l}88 \cdot 0 \\
95 \cdot 7 \\
98 \cdot 9\end{array}$ & $\begin{array}{l}70 \\
69 \\
68\end{array}$ & $\begin{array}{l}178 \\
175 \\
173\end{array}$ & $\begin{array}{r}1.3 \\
2 \cdot 3 \\
7 \cdot 0\end{array}$ & $\begin{array}{l}68 \\
68 \\
80\end{array}$ \\
\hline
\end{tabular}

\section{Effect of Intravenous Tolbutamide or Insulin on Fasting Levels of Human Growth Hormone}

Intravenous tolbutamide or insulin administered after an overnight fast produced an expected and variable hypoglycaemia in a mixed group of subjects (Table II). In the presence of a functioning pituitary gland the hypoglycaemia induced significant increases in the levels of circulating growth hormone (cf. $\mathrm{D}, \mathrm{L}, \mathrm{R}, \mathrm{S}$ ). A rise in the blood sugar towards normal levels was accompanied by a fall in the growth-hormone levels. In the absence of the pituitary (subject $N$ ) no growth hormone was detected in the fasting blood sample, and a marginal hypoglycaemia over a 90-minute period did not evoke a measurable secretion of growth hormone.

In subjects studied for possible hypopituitarism, hypoglycaemia evoked no measurable response in pituitary growth hormone in two subjects ( $P$ and $U$ ). The absence of a response in one subject $(T)$ suggested hypopituitarism, but a repeat test after more pronounced hypoglycaemia was not possible. In two further subjects ( $M$ and $O$ ) the hypoglycaemia induced was not intense, but significant increases in plasma-growth-hormone levels were obtained. The remaining subject $(Q)$ undergoing investigations for spontaneous hypothermia showed a small but significant response to a marked hypoglycaemia.

The results suggest that the measurement of plasma-growthhormone levels after an induced hypoglycaemia is a direct test of the presence or absence of pituitary function for this hormone. However, greater standardization is required before degrees of pituitary impairment can be recognized.

It may be noted that an increased secretion of growth hormone was observed during an hypoglycaemia induced by metyrapone. A rise in growth hormone from 4 to $19.4 \mu \mathrm{mg} . / \mathrm{ml}$. took place as the blood-sugar level fell from 76 to $54 \mathrm{mg} . / 100$ $\mathrm{ml}$. during a three-and-three-quarter-hour intravenous infusion of metyrapone.

\section{Effect of Strenuous Exercise on Fasting Level of Human Growth Hormone}

After an overnight fast (14 hours) three normal men and one normal woman were exercised for two hours in a competitive game (squash rackets) by a succession of unfasted players. Blood samples were taken before and immediately after the exercise period. Thereafter oral glucose was given and a blood sample taken 30 minutes later. In the three men, growth hormone increased (fourfold, eightfold, and seventeenfold) over the fasting level, but the changes were not correlated with changes in the blood sugar. The results in the fasted men showed that growth-hormone secretion, marginally stimulated by an overnight fast, was further stimulated by an increased demand for energy substrates during strenuous exercise (Table III).

In the only woman the growth-hormone level was significantly decreased after exercise from a very high initial level and the fall was correlated with a relative hyperglycaemia. The results suggested that the mild hypoglycaemia of overnight fasting had already stimulated a marked hypersecretion of growth hormone. The hyperglycaemic effect of the adrenal-corticoids was not studied and might be expected to play a part, particularly in this case. It may be inferred that the additional demands of exercise were met in this way and a rise in blood sugar was followed by the observed reduction in growth hormone.

\section{Effect of Glucose Administration on Growth-hormone Secretion}

A marked reduction in plasma-growth-hormone levels after oral glucose has been demonstrated by Roth et al. (1963a, $1963 \mathrm{~b}$ ) and the results obtained with the two men (E and F, Table III) are in accord with their findings. However, the effect of oral glucose in the woman (G. Table III) must be considered anomalous, since no significant effect on the blood sugar was observed 30 minutes after the glucose load, but the growth-hormone level had been reduced by half.

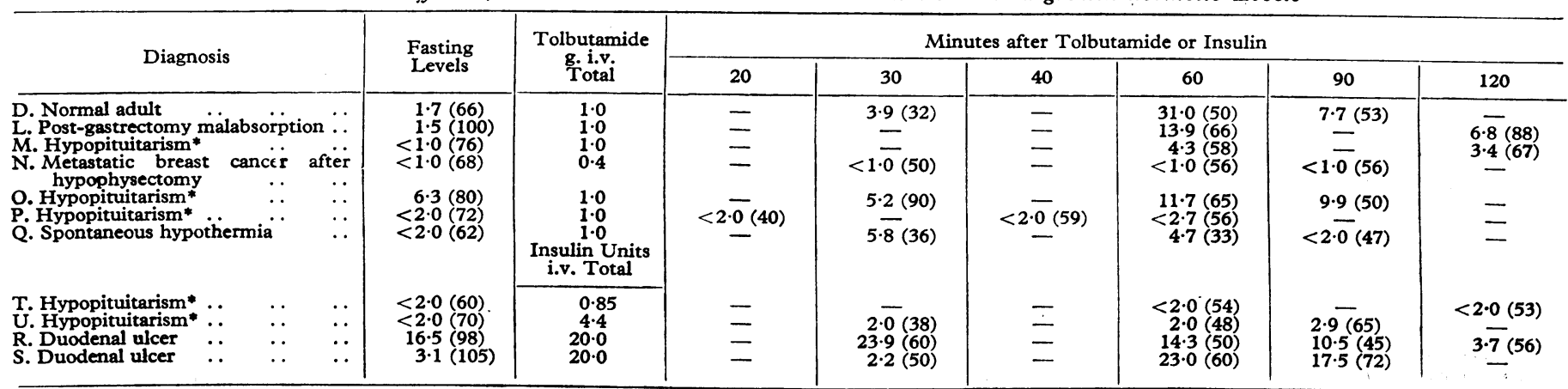


The reduction in the levels of growth reported by Roth et al. (1963a, 1963b) and shown by the two men (Table III) approximate to the half-life of injected growth hormone of 26-27 minutes found by Utiger, Parker, and Daughaday (1962) and Hunter and Greenwood (1964). A more precise calculation of the rate at which endogenous growth hormone disappears from the plasma after glucose is possible from the data shown in the Chart. Intravenous glucose $(25 \mathrm{~g}$.) was administered to a patient with a malignant islet-cell tumour. A logarithmic plot of the growth-hormone levels from 5 to 30 minutes was linear with time and the half-life was calculated to be 19.0 minutes. In a similar experiment the half-life of endogenous growth hormone was found to be 20 minutes (Dr. S. A. Berson, personal communication).

TABle III.-Effect of Overnight Fasting Followed by Strenuous Exercise and Oral Glucose on Plasma-growth-hormone Levels

\begin{tabular}{|c|c|c|c|c|c|c|c|c|}
\hline \multirow{2}{*}{ Subject } & \multirow{2}{*}{ Age } & \multicolumn{2}{|c|}{ Weight } & \multicolumn{2}{|c|}{ Height } & \multirow{2}{*}{$\begin{array}{l}\text { Fasting } \\
\text { Levels }\end{array}$} & \multirow{2}{*}{$\begin{array}{c}\text { After } \\
2 \mathrm{hr} \\
\text { Exercise }\end{array}$} & \multirow{2}{*}{$\begin{array}{l}30 \mathrm{~min} . \\
\text { after } \\
\text { Oral } \\
\text { Glucose }\end{array}$} \\
\hline & & lb. & kg. & in. & $\mathrm{cm}$. & & & \\
\hline $\begin{array}{l}\text { B. Normal man } \\
\text { F. Normal man } \\
\text { C. Normal man } \\
\text { G. Normal woman }\end{array}$ & $\begin{array}{l}27 \\
36 \\
30 \\
24\end{array}$ & \begin{tabular}{l|}
170 \\
189 \\
147 \\
110
\end{tabular} & $\begin{array}{l}77 \cdot 1 \\
85 \cdot 7 \\
66 \cdot 7 \\
49 \cdot 9\end{array}$ & $\begin{array}{l}70 \\
70 \\
69 \\
67\end{array}$ & $\begin{array}{l}178 \\
178 \\
175 \\
170\end{array}$ & $\begin{array}{c}1 \cdot 2(70) \\
1 \cdot 6(102) \\
<1 \cdot 0(80) \\
46 \cdot 0(78)\end{array}$ & \begin{tabular}{|c|}
$4 \cdot 6(68)$ \\
$14 \cdot 7(80)$ \\
$10 \cdot 9(96)$ \\
$30 \cdot 0(100)$
\end{tabular} & $\begin{array}{l}<1.0(96) \\
1.6(112) \\
14.0(92)\end{array}$ \\
\hline
\end{tabular}

Values for growth hormone are expressed as $\mu \mathrm{mg}$. $/ \mathrm{ml}$. plasma. Blood-sugar levels (mg./100 ml.) are given in parentheses.

Glucose $(50 \mathrm{~g}$.) was given after the exercise period was completed.

This correspondence between the rates at which injected and secreted growth hormone disappears from the plasma suggests that glucose administration "switches off" growth-hormone secretion by the pituitary.

\section{Effect of Oral Protein on Fasting Levels of Growth Hormone}

The reduction in growth hormone following oral glucose and the anomaly noted in the normal woman subject suggested that growth-hormone secretion might be reduced by other factors. The effect of feeding protein in this subject and two normal men was therefore studied after the stimulation of growth hormone by overnight fasting. Stimulation was not achieved in one normal man (B. Table IV) and the ingestion of protein had no effect on the plasma-growth-hormone levels and no significant effect on blood sugar. In the second normal man, growth-hormone secretion was stimulated by the overnight fast (8.1 $\mu \mathrm{mg} . / \mathrm{ml}$.$) . From one to two hours after the fast had been$ terminated by feeding protein, growth-hormone levels were significantly lower $(2.8 \mu \mathrm{mg} . / \mathrm{ml}$.) but without any marked changes in the blood sugar. The normal woman, who had previously given anomalous results, showed again an intense stimulation in growth-hormone secretion after an overnight fast (116 $\mu \mathrm{mg} . / \mathrm{ml}$.) with a normal fasting blood sugar $(68 \mathrm{mg} . / 100$ ml.). One hour after the ingestion of protein the high level of growth hormone had decreased by $50 \%$ but the blood sugar was virtually unchanged.

These preliminary results suggest that growth hormone, stimulated by fasting, can be reduced by oral protein without marked changes in the fasting blood sugar.

\section{Discussion}

Human-growth-hormone levels in the plasma of normal adults show rapid increases in response to varying degrees of hypoglycaemia induced physiologically or experimentally, as first reported by Roth et al. (1963a, 1963b). The administration of glucose to normal subjects suppressed human-growthhormone secretion. The results reported here are in agreement with their findings and also show that the demand for increased energy substrates may stimulate growth-hormone secretion without changes in blood sugar.

The studies on the levels of plasma growth hormone suggest that variations in the secretion of this hormone by the pituitary in response to varying degrees of hypoglycaemia or demands for energy substrates is an important function in the sparing of blood glucose. The response of human growth hormone to a generally increased demand for energy substrates is in accord with the lipid mobilizing activity of administered human growth hormone (Raben and Hollenberg, 1959). The striking increase in free fatty acids after fasting for three days and the rapid fall on oral glucose (Unger, Eisentraut, and Madison, 1963) parallel the changes observed by Roth et al. (1963a) in plasma growth hormone after a similar period of fasting.

The measurement of plasma cortisol after an insulin-induced hypoglycaemia has been suggested as a rapid and simple test of adrenocortical function (Landon, Wynn, and James, 1963). The results shown here suggest that growth-hormone estimations carried out at the same time would provide a test of pituitary function in addition to the assessment of adrenocortical function.

The results of feeding protein in normal adults show that pituitary-growth-hormone secretion can be reduced without marked changes in the fasting blood sugar. The fall in growth hormone levels on protein-feeding is not consistent with the absolute "switch off" of pituitary growth hormone by glucose shown by the correspondence between the half-lives of exogenous and endogenous growth hormone. The mechanism involved requires further studies of the effect of intravenous amino-acids on growth-hormone secretion in normal adults and children.

\section{Summary}

Plasma-growth-hormone levels were marginally increased by the mild hypoglycaemia induced by overnight fasting. Marked increases were obtained by a further lowering in the blood sugar by means of intravenous injections of insulin or tolbutamide. Results obtained in normal, hypopituitary, and hypophysectomized subjects after insulin or tolbutamide suggest that the procedure could be used to assess pituitary function. Increases in plasma-growth-hormone levels without marked changes in the fasting blood-sugar were obtained after strenuous exercise in normal adults.

The administration of glucose causes the level of plasma growth hormone to fall at the same rate as that found for the disappearance of growth hormone injected intravenously. The "switch off" in pituitary secretion after glucose was not found after oral protein although the latter reduced the level of circulating hormones.

We wish to thank Dr. G. F. Marrian, F.R.S., for his encouragement of this work. We are indebted to clinical colleagues for their help and interest at Alder Hey Children's Hospital, Guy's Hospital, the London Hospital, the National Hospital, New End Hospital, St. Bartholomew's Hospital, St. Mary's Hospital, Westminster Children's Hospital, and Westpark Hospital. The skilled technical

\begin{tabular}{|c|c|c|c|c|c|c|c|c|c|c|c|c|}
\hline \multirow{2}{*}{\multicolumn{4}{|c|}{ Subject }} & \multirow{2}{*}{ Age } & \multicolumn{2}{|c|}{ Weight } & \multicolumn{2}{|c|}{ Height } & \multirow{2}{*}{$\begin{array}{l}\text { Fasting } \\
\text { Levels }\end{array}$} & \multirow{2}{*}{$\begin{array}{l}\text { Protein } \\
\text { Ingested g.* }\end{array}$} & \multirow{2}{*}{$\frac{\text { Time After }}{1 \mathrm{hr} .}$} & \multirow{2}{*}{$\begin{array}{l}\text { Oral Protein } \\
2 \mathrm{hr} .\end{array}$} \\
\hline & & & & & lb. & kg. & in. & $\mathrm{cm}$. & & & & \\
\hline $\begin{array}{l}\text { B. Normal man } \\
\text { F. Normal man } \\
\text { G. Normal woman }\end{array}$ & $\begin{array}{l}. \\
\because\end{array}$ & $\begin{array}{l}. \\
\because\end{array}$ & $\begin{array}{l}. \\
\because .\end{array}$ & $\begin{array}{l}36 \\
36 \\
24\end{array}$ & $\begin{array}{l}140 \\
189 \\
110\end{array}$ & $\begin{array}{l}63.5 \\
85.7 \\
49.9\end{array}$ & $\begin{array}{l}69 \\
70 \\
67\end{array}$ & $\begin{array}{l}175 \\
178 \\
170\end{array}$ & $\begin{aligned}<1.0(78) \\
8.1(82) \\
116.0(68)\end{aligned}$ & $\begin{array}{l}50 \\
40 \\
50\end{array}$ & $\begin{array}{r}<1.0(70) \\
2.5(70) \\
58.0(72)\end{array}$ & $\begin{array}{l}<\begin{array}{l}1.0(70) \\
2.8(68)\end{array}- \\
-\end{array}$ \\
\hline
\end{tabular}

" Milk protein ("casilan"). Values for growth hormone are expressed as $\mu \mathrm{mg} / \mathrm{ml}$. plasma. Blood-sugar levels (mg./100 ml.) are given in parentheses. 
assistance of Miss C. Harris and Mrs. H. Coats is gratefully acknowledged.

\section{REFERENCES}

Glick, S. M., Roth, J., Yalow, R. S., and Berson, S. A. (1963). Nature (Lond.), 199, 784.

Greenwood, F. C., Hunter, W. M., and Klopper, A. (1964). Brit. med. f., 1,22
Hunter, W. M., and Greenwood, F. C. (1962). Biochem. 7., 85, 39P. Lan (1964). Ibid., 91, 43.

Landon, J., Wynn, V., and James, V. H. T. (1963). 7. Endocr., 27, 183. Raben, M. S. (1959). Recent Progr. Hormone Res., 15, 71.

- and Hollenberg, C. H. (1959). 7. clin. Invest., 38, 484

Roth, J., Glick, S. M., Yalow, R. S., and Berson, S. A. (1963a). Science, 140, 987.

(1963b). Metabolism, 12, 577.

Unger, R. H., Eisentraut, A. M., and Madison, L. L. (1963). F. clin. Invest., 42, 1031.

Utiger, R. D., Parker, M. L., and Daughaday, W. H. (1962). Ibid., 41, 254.

\title{
Mannitol Therapy in Oliguria of Acute Onset
}

\author{
H. E. ELIAHOU,* B.A., M.D.
}

Brit. med. F., 1964, 1, 807-809

The protective action of mannitol on the ischaemic kidney was noted by Selkurt (1945) and reaffirmed experimentally by Hatcher et al. (1958) and Hostnik et al. (1959). Recent reports (Powers et al., 1957 ; Barry et al., 1961a, 1961b ; Lempert et al., 1961 ; Nesbit et al., 1962 ; Barry and Malloy, 1962 ; Seitzman et al., 1963) claim that the process of acute renal failure can be prevented or even reversed by the use of intravenous mannitol, provided this treatment is instituted early. But in all the clinical cases presented there is some doubt about whether actual reversal of acute renal failure had taken place. Experimental support of reversal has, however, been obtained. Murphy et al. (1963) have shown a definite increase in the directly measured renal blood-flow during sustained haemorrhagic hypotension in dogs, without having increased the blood-volume. Leonhardt and Landes (1963) found that infusion of mannitol in six dehydrated patients increased the partial pressure of oxygen in the urine from a mean of $29 \mathrm{~mm}$. to a mean of $67 \mathrm{~mm}$. $\mathrm{Hg}$, an average rise of $124 \%$.

Our intention was to examine the possible beneficial effects of mannitol clinically, and to investigate whether reversal of acute renal failure does actually occur. If proper evaluation of mannitol therapy is to be attempted, its effect in oliguria of extrarenal origin and in oliguria of true renal origin should be considered separately. In this study this differentiation has been attempted, using the power of the kidneys to concentrate as the criterion. It has been shown by Gullick and Raisz (1960) that the concentrating ability, though markedly decreased during operation, returns toward pre-operative values the next day. It therefore follows that any serious decrease in the concentrating ability of the kidneys in the presence of oliguria, later than 24 hours post-operatively, would seem to indicate incipient acute parenchymatous renal failure, provided the kidneys were normal prior to the operation.

\section{Methods}

This study is based upon the finding that in oliguria of extrarenal origin, when the kidneys are still normal, the urinary urea concentration and the urine osmolality are high; the urine-urea concentration being well over $1,500 \mathrm{mg} . / 100$ ml. (Shackman et al., 1960 ; Molloy, 1962 ; Eliahou, 1963) and the urine osmolality being at least two and a half times that of the plasma (Jacobson et al., 1962), whereas in acute renal failure the kidneys fail to concentrate and the urinary urea and osmolality tend to approach that of the blood.

* From the Nephrology Unit, Tel-Hashomer Government Hospital, TelHashomer, Israel.
Only patients whose kidneys. functioned well prior to the onset of oliguria were considered. This was determined in the general-hospital wards by the absence of a history of serious renal disease, by a normal specific gravity, by the presence of a normal creatinine clearance, and by a normal blood-urea level. In the few emergency cases an adequate history of no renal disease, together with a previous negative routine check-up of the urine, sufficed. To avoid the transient decrease in the concentrating ability during operations (Gullick and Raisz, 1960), the urines of all the surgical patients included in this study were first examined, and mannitol was administered, at least 24 hours after the end of the operation.

Samples of fresh urine were taken from the patients soon after oliguria was established and were examined for osmolality and urea concentration. Osmolality was always promptly determined. If the samples were taken at night the urea was determined the next day, after having covered the urine with toluol and stored it in a refrigerator. Fresh samples of urine were examined the next morning after the administration of mannitol. This was usually within 10 to 18 hours after its infusion.

Urine-urea concentration was determined by the Technicon autoanalyzer. Urine osmolality was determined by the Fiske osmometer.

In all the patients, excepting Case 1 (see Table and case report), $250 \mathrm{ml}$. of $10 \%$ mannitol was rapidly infused intravenously at the rate of 80 to 100 drops a minute. This was followed by intravenous fluids according to the requirements of the individual patient, depending upon the fluid balancesheet.

\section{Results}

\section{Oliguric Patients with Low Urine Concentration}

Ten severely ill patients are included in this group. Except for the case of severe heat-stroke, they were all surgical cases (see Table). These patients at the time of examination, after the onset of oliguria, had a low urinary urea concentration as well as a low urine osmolality, in spite of a rise in blood urea. The values were not low enough to justify the diagnosis of acute renal failure. However, they were not high enough to be compatible with the diagnosis of normal kidneys. Since acute renal failure takes some time to develop, it is possible to interpret these findings as being compatible with partial or "incipient" renal failure. According to the clinical events and the laboratory data, therefore, the cases described could 